\title{
Kent gelişiminde sürdürülebilirliği yakalama kaygısı: Bartın örneği
}

\author{
Concern for sustainability in urban development strategies: case of Bartın
}

\author{
Cansu DİNÇTÜRK*1,a, Sebahat AÇIKSÖZ ${ }^{1, b}$ \\ ${ }^{1}$ Bartın Üniversitesi, Mühendislik ve Mimarlık Fakültesi, Peyzaj Mimarlı̆̆ı Bölümü, 74100, Bartın
}

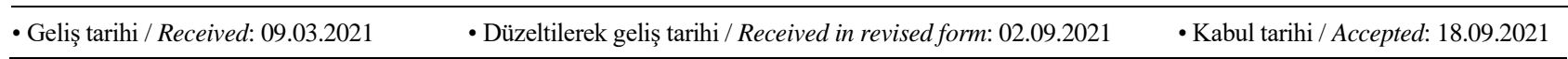

\begin{abstract}
$\ddot{O} z$
Kentsel gelişim süreçlerinin kentte yarattığı baskının azaltılması, hizmetlerin her bireye eşit olarak sunulması ve doğal kaynakların sürdürülebilirliğinin sağlanmasında kent gelişim stratejilerinin (KGS) önemi büyüktür. Bu araştırma kapsamında ilk olarak, Bartın İli Stratejik Planı (2020-2024) ile kent gelişiminde ele alınması gereken temalar karşılaştırılarak analiz edilmiştir. Bir diğer analiz aşamasında ise; kentsel planlama ve yönetime ilişkin ölçütlere ve stratejik hedeflerin "Bütünleşik Kentsel Gelişme Stratejisi ve Eylem Planı- KENTGES, 2010-2023" ile uyumunun belirlenmesine ilişkin, ilişki matrisleri oluşturulmuştur. Matrislerde yer alan veriler; uyumlu, dolaylı uyumlu ve tam uyumlu şeklinde sınıflandırıldıktan sonra, dolaylı uyumlu olarak ilişkilendirilen maddeler ve nedenleri de kısaca özetlenmiştir. Elde edilen karşılaştırmalar sonucunda, Bartın'ın kentsel gelişim stratejilerinin eksik yönleri belirlenenmiş ve sürdürülebilir kent gelişiminin sağlanmasına yönelik önerilere yer verilmiştir.
\end{abstract}

Anahtar kelimeler: Bartın, İlişki matrisi, Kent gelişim stratejileri, KGS, Sürdürülebilir kent gelişimi

\begin{abstract}
City development strategies (CDS) are of great importance in reducing the pressure created by urban development processes in the city, providing services equally to each individual and ensuring the sustainability of natural resources. Within the scope of this research, firstly, Bartın Province Strategic Plan (2020-2024) was analyzed by comparing themes that should be addressed in urban development. In another analysis phase, relationship matrices were created to determine the harmony of the criteria and strategic goals of urban planning and management with the "Integrated Urban Development Strategy and Action Plan - KENTGES, 2010-2023". Data in matrices; after classifying them as compatible, indirect compatible and full compatible, the items associated with indirect compatible and their reasons are briefly summarized. As a result of the comparisons obtained, the deficiencies of Bartın's urban development strategies were determined and suggestions for ensuring sustainable urban development were given.
\end{abstract}

Keywords: Bartın, Relationship matrix, City development strategies, CDS, Sustainable city development

\footnotetext{
*a Cansu DİNÇTÜRK; cansuyuce1994@gmail.com, Tel: +90 (546) 941 7366, orcid.org/ 0000-0002-5427-773X

${ }^{\mathrm{b}}$ orcid.org/000-0002-2673-9236
} 


\section{Giriş \\ 1.Introduction}

1972 yılından itibaren Birleşmiş Milletler (BM) İnsan ve Çevre Konferansı'nda gündeme gelen, Rio Zirvesi, Gündem 21, Habitat II ve Johannesburg Zirvesi gibi uluslararası toplantılarda gerçekleştirilen uygulama ve hedefler kentsel planlama alanına da etki etmiştir. $\mathrm{Bu}$ kapsamda "sürdürülebilir kentler oluşturulması düşüncesi" 21. yüzyılda kent planlama disiplininin temel hedeflerinden biri olarak ele alınmaya başlanmıştır. Geliştirilen sürdürülebilir hedefler dahilinde; doğal kaynakların korunması, çevre kirliliğinin önlenmesi, kaynakların etkin/verimli bir şekilde kullanılması, arazinin yatay değil dikey olarak değerlendirilmesi ve kentsel hareketliliğin en aza indirgenmesi vb. amaçlanmaktadır (Karakurt Tosun, 2013).

Kent çeperindeki büyümeler, kentsel alan ve tarım alanları arasında çatışmalar yaşanmasına neden olmaktadır. Kentsel ve kırsal alanlardaki ayrımlara meydan okunmasında doğa temelli değerlerin önemi büyüktür. $\mathrm{Bu}$ bağlamda yapılan bir çalışmada (Nilsson vd., 2020) Avrupa'nın 6 kenti incelenmiş ve sürdürülebilir/ doğa dostu kent gelişimine ilişkin aşağıdaki stratejiler oluşturulmuştur:

- Kentsel sınırda konut üzerindeki baskının azalt1lmas1,

- Kentsel sinırda tarımın güçlendirilmesi,

- Turizm ve rekreasyonun bölgesel kalkınma ile sürdürülebilir bir şekilde entegre edilmesi,

- Kentsel sınırda yüksek değerli doğa alanlarının korunmas1.

Günümüz koşullarında sermaye, kültür ve yenilik merkezi olan, milyonlarca insana ev sahipliği yapan kent yerleşimleri aynı zamanda enerji tüketimi ve çevre kirliliği gibi olumsuz durumlara da neden olmaktadır. Günümüzde sürekli genişleme ve yayılma durumunda olan kentsel yerleşimler, doğal kaynak tüketimi ve arazi kullanımı bakımından "sürdürülemez" bir durumdadir (Sat vd., 2017).

Kentte yaşanan ani nüfus artışları, konut ihtiyacını artırmış ve bu bağlamda kent yerleşimlerinin hızlı bir şekilde dışa doğru yayılmasına neden olmuştur. $\mathrm{Bu}$ kontrolsüz ve plansız gelişme tarım alanları, meralar ve orman alanları gibi önemli ekolojik noktalar üzerinde baskı oluşturmuştur. Büyümesi artık kontrol edilemez bir duruma gelen kentsel alanlarda kent yönetimi sorunları ortaya çıkmaya başlamıştır. Kent yönetiminde kontrolün sağlanmasında uzun ömürlü planlama stratejilerinin oluşturulması önemli bir unsurdur (Vural vd., 2019). Bu bağlamda Parnell \& Robinson (2016)'ya göre; kentsel sorunlara bir çözüm niteliği taşıyan, kent gelişiminin doğru bir şekilde gerçekleştirilmesinin amaçlandığ 1 Kent Gelişim Stratejisi (KGS) önemli bir yaklaşımdır. Bu yaklaşımda, mevcut kentsel firsat ve ekonomik sorunlara yanıt verilmesini amaçlayan stratejiler yer almaktadır (Rasoolimanesh vd., 2011). BMHABİTAT (2005)'e göre KGS; şehirlerde adil büyüme amacıyla geliştirilmiş, sürdürülebilir bir eylem planıdır. Bu eylem planında; katılım yoluyla toplulukların yaşam kalitelerinin iyileştirilmesi, çevre koşullarının iyileştirilmesi ve yoksulluğun azaltılmasına yönelik stratejiler yer almaktadır. Kalkınmada katılımcı planlamanın gerekçeleri; toplu sorumluluk duygusunun güçlendirilmesi, yerel kaynakların seferber edilmesi, toplumun ihtiyaçlarını karşılayan projelere yer verilmesi, adil kaynak dağılımının teşvik edilmesi ve şeffaflık ile hesap verilebilirliği artırması şeklinde özetlenebilir (UN Habitat, 2005). Sürdürülebilir kalkınma/ ekonomi/ çevre konularında gelişim ve ilerleme gösterilmesinde ulusal veya uluslararası ölçekteki eylem planlarının önemi büyüktür (KENTGES, 2020).

Türkiye hızlı kentleşme sürecinin yaşandığı ülkelerden birisidir (Özbilen \& Gülersoy, 2016). Ülkemizde kentleşme hareketi ile başlayan şehirlerin fiziksel yapılarında meydana gelen değişimler birçok sorunun çıkış noktasını oluşturmaktadır. Çakır (2011)'e göre kentte yaşanan mimari değişimler, konut sayılarındaki artış ve buna bağlı olarak yeşil alan miktarının azalması gibi sorunlar fiziksel olarak gözle görülebilen durumlardır (Güven, 2017). Türkiye'de yaşanan fiziksel sorunlardan biri olan konut problemi, kentleşmenin başlangıcı olarak kabul edilen 1950'li y1llarda kentsel mekânda etkisini göstermeye başlamıştır. $\mathrm{Bu}$ etki; ekonomik, sosyal, mekânsal sorunlara neden olmuş ve beraberinde gecekondu alanları ve çarpık kent morfolojisinin gelişmesine neden olmuştur (Ören \& Yüksel, 2013). Ertürk (2011)'e göre sözü edilen gecekondu bölgeleri, kentin fiziki yapısıyla ilgili gibi gözüken aslında kişilerin ekonomisi, eğitimi, gelir durumu gibi olgularla ilişkili kentsel sorunlardandır (Güven, 2017). Ülkemizde nüfusun artan oranlarda büyük şehirlerde yoğunlaştı̆̆ görülmektedir. $\mathrm{Bu}$ durum büyük şehirlerde; işsizlik, güvenlik sorunları, hizmet yetersizlikleri ve cinsiyet eşitliğinin sağlanamaması gibi birçok sorunun yaşanmasına neden olmaktadır. $\mathrm{Bu}$ bağlamda ülkemizde, kentsel yerleşmelerin mekânsal şartlarının iyileştirilmesi, ekonomik/ 
toplumsal yapının güçlendirilmesi ve mekânsal planlama sisteminin tekrar gözden geçirilmesine duyulan gereksinim artmaktadır. Bu bağlamda geliştirilen "Kentsel Gelişme Stratejisi ve Eylem Planı (KENTGES)" sözü edilen gereksinimlerin karşılanmasına yönelik bir çözüm önerisidir (Güler \& Turan, 2013). Türkiye'nin kentleşme, imar ve mekânsal planlamaya ilişkin sorunlarından yola çıkılarak hazırlanmış "Kentleşme Şûrası Önerileri" (2009) isimli rapor (KENTGES, 2020) KENTGES için önemli bir altlıktır. KENTGES eylem planı 2010-2023 yıllarını kapsayan, kentleşme, yerleşme ve mekânsal planlamaya ilişkili değerlerin benimsendiği bir düşünce ekseninde, ulusal ölçekte referans belgesi özelliği taşıyan stratejik bir dokümandır. $\mathrm{Bu}$ stratejik dokümanda, kentleşmenin yapısal sorunlarının giderilmesi, sağlık ve yaşam kalitesinin artırılması, kentsel gelişmenin sağlanmasına ilişkin ilke ve eylemler yer almaktadır. KENTGES'in temel stratejileri; mekânsal planlama sisteminin yeniden yapılandırılması, mekân ve yaşam kalitelerinin artırılmas1, ekonomik ve toplumsal durumun iyileştirilmesi olarak belirtilmiştir (KENTGES, 2020).

Araştırmada, Bartın ilinin kent gelişim stratejilerinin, güncel dokümanlar aracılığıyla değerlendirilmesi/olumlu-olumsuz yönlerinin ölçülmesi amaçlanmıştır. $\mathrm{Bu}$ kapsamda, Rasolimanes vd., 2012, Wong vd., 2016, KENTGES, 2020 dokümanları ile Bartın Stratejik Planı (2020-2024) arasinda kiyaslamalar gerçekleştirilerek, geliştirilen matrisler aracılığıyla uyum düzeylerine ilişkin değerlendirmelerde bulunulmuştur.

\section{Materyal ve yöntem \\ 2. Material and method}

Araştırma kapsamında öncelikle araştırmanın amacı belirlenmiş, alana ilişkin tespitlerde bulunulduktan sonra; konuya ve stratejik dokümanlara ilişkin araştırmalar gerçekleştirilmiştir. Elde edilen dokümanlar arasında kıyaslamalar gerçekleştirildikten sonra ise çeşitli değerlendirmelerde bulunulmuştur. En son aşamada; Bartın kentine ilişkin kentsel planlama sistemi/ mekân- yaşam kalitesi/ ekonomiktoplumsal yapıya ilişkin etkili olacağı düşünülen öneriler geliştirilmiştir.

$\mathrm{Bu}$ araştırmada, Bartın ilinin kent gelişim stratejilerinin, güncel doküman ve belgeler aracılığıyla değerlendirilmesi amaçlanmıştır. Kent gelişim stratejileri ve Bartın Belediyesi'ne ait dokümanlara ilişkin taramalar gerçekleştirildikten sonra, dokümanlar arasında kıyaslama yapılması amaciyla matrisler oluşturulmuştur. Kıyaslama yapılan dokümanlar ve nedenleri Tablo 1'de yer almaktadır. Matrislerin uyum dereceleri ve nedenleri ise aşağıdaki gibidir:

- "Uyumlu" olarak nitelendirilen konulara stratejik planda yer verilmiştir.

- "Dolaylı uyumlu" olarak nitelendirilen başlıkların birbirleriyle ilişkilendirilme nedenleri Tablo 2 ve 3'te yer almaktadır.

- Karşılaştırma yapılan iki konu arasında ilişki saptanamayan başlıklar ise "Uyumsuz" olarak nitelendirilmiştir.

Tablo 2 ve 3'te yer alan "kaynaklar" konu kapsamı ve bağlamı nedeniyle savunulan düşünce ile uyum sağlamakta olduğundan, seçilerek ilişkilendirme gerçekleştirilmiştir. Bu kapsamda, verilere ilişkin taramalar gerçekleştirilmiş olup en ilişkilendirilebilir kaynak referans alınmıştır.

Tablo 1. Kiyaslama yapılan dokümanlar ve nedenleri.

Table 1. Compared documents and reasons

\begin{tabular}{lll}
\hline 1.Doküman & 2.Doküman & Kıyaslanma Nedeni \\
\hline $\begin{array}{l}\text { Rasolimanes vd., } \\
2012\end{array}$ & $\begin{array}{l}\text { Kent gelişiminde ele alınması gereken beş ana tema } \\
\text { üzerinden içerik analizi }\end{array}$ \\
$\begin{array}{ll}\text { Bartın Stratejik } \\
2020 \\
(2020-2024)\end{array}$ & $\begin{array}{l}\text { Planı, } \\
\text { Kentsel planlama ve yönetime ilişkin ölçütlere uyumun } \\
\text { belirlenmesi }\end{array}$ \\
$\begin{array}{l}\text { KENTGES, 2016 2020 } \\
(2010-2023)\end{array}$ & $\begin{array}{l}\text { Stratejik hedeflerin KENTGES ile uyumunun tespit } \\
\text { edilmesi }\end{array}$ \\
\hline
\end{tabular}


Tablo 2. Sürdürülebilir kent gelişimine ilişkin dolaylı ilişkiler ve nedenleri.

Table 2. Indirect relationships and reasons for sustainable urban development

\begin{tabular}{|c|c|c|}
\hline Dolaylı İlişki & Kaynak & İlişkilendirme Nedeni \\
\hline & Gür \& Erbil, 2018) & $\ldots$ \\
\hline $\begin{array}{l}\text { Kentsel hizmetler/ } \\
\text { çalışma koşulları }\end{array}$ & $\begin{array}{l}\text { (Kömürcü \& Avşar } \\
\text { Negiz, 2016) }\end{array}$ & $\begin{array}{l}\text { Hizmetlerin iyileştirilmesinde, çalışma ve yaşam } \\
\text { koşullarının önemi vurgulanmıştır. }\end{array}$ \\
\hline $\begin{array}{l}\text { Yeterli erişim/ çalışma } \\
\text { koşulları }\end{array}$ & (Akbulut, 2016) & $\begin{array}{l}\text { Erişilebilirlik, kent hayatının } \\
\text { unsurlarından biri olarak ele alınmıştır. }\end{array}$ \\
\hline $\begin{array}{l}\text { Açık-yeşil } \\
\text { yeterli erişim }\end{array}$ & $\begin{array}{l}\text { (Önder \& Polat, } \\
\text { 2012) }\end{array}$ & $\begin{array}{l}\text { Açık-yeşil alanlara etkin erişimin önem ve gerekliliğine } \\
\text { değinilmiştir. }\end{array}$ \\
\hline $\begin{array}{l}\text { Açık-yeşil alanlar/ hava } \\
\text { kalitesi ve atı yönetimi }\end{array}$ & (Gül \& Küçük, 2001) & $\begin{array}{l}\text { Açık-yeşil alanların sürdürülebilir koruma/ kullanımı } \\
\text { savunulmuştur. }\end{array}$ \\
\hline $\begin{array}{l}\text { Atık } \\
\text { biyoçeşitlilik }\end{array}$ & (Demirayak, 2002) & $\begin{array}{l}\text { Atıkların etkin bir şekilde yönetilememesinin } \\
\text { biyoçeşitliliğge etkilerine değinilmiştir. }\end{array}$ \\
\hline $\begin{array}{l}\text { Engelli bireyler/ konut } \\
\text { erişimi }\end{array}$ & (Demirkan, 2015) & $\begin{array}{l}\text { Özel gereksinimi olan bireylerin, çeşitli bina ve } \\
\text { kullanımlara erişimi bir gereklilik olarak belirtilmiştir }\end{array}$ \\
\hline $\begin{array}{l}\text { Kültürel miras/ } \\
\text { biyoçeşitlilik teşviki }\end{array}$ & $\begin{array}{l}\text { (Öksüz Kuşçuoğlu \& } \\
\text { Taş, 2017) }\end{array}$ & $\begin{array}{l}\text { Doğal dengenin bozulması, kültürel mirası tehdit eden } \\
\text { bir unsur olarak ele alınmıştır. }\end{array}$ \\
\hline
\end{tabular}

Tablo 3. KENTGES dokümanında dolaylı ilişki kurulan başlıklar ve nedenleri -2.

Table 3. The titles that are indirectly related in the KENTGES document and their reasons -2.

\begin{tabular}{lll}
\hline Dolaylı ilişki & \multicolumn{1}{c}{ Kaynak } & Ilişkilendirme Nedeni \\
\hline $\begin{array}{l}\text { Sürdürülebilir kent } \\
\text { formu/ ulaşım }\end{array}$ & (Baş, 2018) & $\begin{array}{l}\text { Sürdürülebilir kent formunun, kent içi erişimi } \\
\text { desteklediği belirtilmiştir. }\end{array}$ \\
$\begin{array}{l}\text { Sürdürülebilir kent } \\
\text { formu/ açık- yeşil } \\
\text { alanlar }\end{array}$ & (Karataş \& Kılıç, 2017) & $\begin{array}{l}\text { Sürdürülebilir kentlerde açık- yeşil alanların kilit } \\
\text { rol üstlendikleri ifade edilmiştir. }\end{array}$ \\
$\begin{array}{l}\text { Sürdürülebilir kent } \\
\text { formu/ kültürel miras }\end{array}$ & (Can, 2014) & $\begin{array}{l}\text { Sürdürülebilir gelişimde, kültürel/ doğal değerlerin } \\
\text { önemi vurgulanmıstır. }\end{array}$ \\
$\begin{array}{l}\text { Sürdürülebilir kent } \\
\text { formu/ atık sistemi }\end{array}$ & (Ulubaş \& Kocabaş, 2016) & $\begin{array}{l}\text { Kentsel sürdürülebilirliğin sağlanmasında atık } \\
\text { yönetiminin önemine değinilmiştir. }\end{array}$ \\
$\begin{array}{l}\text { Altyapı hizmetleri/ } \\
\text { kültürel miras }\end{array}$ & $\begin{array}{l}\text { (Çakmak \& Y1lmaz, 2017) } \\
\text { Kültürel miras yönetiminde alt yapıya ilişkin } \\
\text { uygulamaların önemine değinilmiştir. }\end{array}$ \\
$\begin{array}{l}\text { Açık- yeşil alan } \\
\text { sistemi/ } \\
\text { altyapı hizmetleri }\end{array}$ & $\begin{array}{l}\text { (Yücesu vd., 2017) } \\
\text { Doğal- kültürel } \\
\text { değerler/ atık sistemi }\end{array}$ & $\begin{array}{l}\text { Ulaşım akslarının, açık- yeşil alan bütünlüğünün } \\
\text { sağlanmasında büyük önem taşıdığı ifade edilmiştir. }\end{array}$ \\
\hline
\end{tabular}




\section{Bulgular ve tartışma}

3. Results and discussion

\subsection{KGS temalarının analizi}

\subsection{Analysis of KGS themes}

Şehirler İttifak1 (Cities Alliance) (2020) verilerine göre; Asya Kalkınma Bankası (Asian Development Bank- ADB), Japon Kalkınma Bankası (Japan Bank for International Cooperation- JBIC) ve Dünya Bankası (World Bank- WB) kuruluşları tarafindan 2005 yılında gerçekleştirilen çalışmada KGS'de ele alınması gereken temalar (çevresel sürdürülebilirlik, geçim kaynakları, finansal kaynaklar, yönetişim) vurgulanmıştır (Rasoolimanesh vd., 2012). Bu temalara ilişskin başlıklar Bartın İli Stratejik Planı (2020-2024)'nda incelenerek aşağıdaki şekilde özetlenmiştir:

\section{CCevresel sürdürülebilirliğe yönelik:}

- Kent siluetinin korunmasına ilişkin uygulamaların artırılması ve yeşil alanların çoğaltılmasına ilişkin çalışmaların gerçekleştirilmesi,

- İnsan odaklı, adil ve erişilebilir bir kent formunun oluşturulması,

- Doğal afetlere hazırlıklı bir kent planının oluşturulması,

- Çevreye duyarlı ulaşım sistemlerinin (bisiklet ve yaya ulaşımı) desteklenmesi ve yoğunluğun azaltılmas1,

- Atıkların çevreci yöntemlerle, ekonomik yarar sağlayacak şekilde dönüştürülmesi,

- Altyapi çalışmalarının gerçekleştirilmesi ve temiz hava kalitesinin devamlılığının sağlanması.

\section{Geçim kaynaklarına yönelik:}

- İstihdamın artırılmasına ilişkin politikalar geliştirilmesi,

- Yerel ürünlerin markalaştırılması ve ekonomiye katkıda bulunulmasına ilişkin faaliyetler gerçekleştirilmesi,

- İl sınırındaki tarımsal faaliyet ve rekâbetlerin desteklenmesi,

- Mesleki eğitim ve beceri kazandırma etkinliklerine yer verilerek, istihdam olanaklarının artırılması.

\section{Finansal kaynaklara yönelik}

- Bütçe disiplininin sağlanması, ek kaynaklarla bütçe gelirlerinin artırılması ve Toplumsal Cinsiyete Duyarlı Bütçeleme (TCBD) uygulamalarına yer verilmesi,

- Kaynakların etkin bir şekilde yönetilmesiyle, risklere karşı korunması,
- Bartın'da yaşayan birey ve ekonomik aktörlere destek sunularak kent ekonomisine katkıda bulunulması.

\section{Yönetissime yönelik}

- Halkın karar alma süreçlerine aktif katılımının sağlanmas1,

- E-belediye uygulamalarının kapsamının genişletilmesi.

\subsection{Sürdürülebilir kent gelişimine ilişkin matrisler}

\subsection{Matrices for sustainable urban development}

Plan içeriği kavrandıktan sonra, Bartın İli Stratejik Planı'nın Wong vd. tarafından geliştirilen "sürdürülebilir kentsel planlama ve yönetim için değerlendirme ölçütlerine" (Wong vd., 2006) uyumluluğunun tespit edilmesi için, Özel Mazlum ve Yalçıner Ercoşkun'dan yararlanılarak ilişki matrisleri geliştirilmiştir (Özel Mazlum \& Yalçıner Ercoşkun, 2019). İlişki matrisi Şekil 1'de yer almaktadir.

- "Konut koşullarına ilişkin" gerçekleştirilen kıyaslamada; çalışma koşulları ve kültürel mirasa dair ilişkilendirilebilir bir madde bulunmadığı görülmüştür. Fakat, kent gelişimi kapsamında gerçekleştirilen uygulamalar ve açık- yeşil alanların say1/ konumları ile ilgili hedeflerden dolayı "uyumlu" olarak belirlenmiştir.

- "Kentsel hizmetlere ilişkin" gerçekleştirilen kıyaslamada, hizmetlerin söz konusu başlıkların çoğunu kapsadığı ancak, çalışma koşullarının iyileştirilmesine ilişkin bir etkinliğin olmadığı saptanmıştır.

- "Yeterli erişim başlığına ilişkin" gerçekleştirilen analizde, kent gelişimi ve entegre bir ulaşım sisteminden bahsedilmiş fakat, kültürel miras alanlarına erişimden bahsedilmemiştir.

- "Sağlık ve eğitim tesisleri konusunda" ise, kent gelişiminde sayı ve niceliklerinin artırılacağından bahsedilmiş fakat, ilgili alanlara ulaşıma yönelik bir bilgiye rastlanmamıştır.

- "Ekonomik büyüme ve istihdam olanaklarının artırılması hususunda" ise, çeşitli kurum ve kuruluşlar vasıtasıyla eğitim ve iş olanaklarının artırılacağına değinilmiştir. Fakat, kültürel miras alanlarının ekonomik büyümeye katkı sunmasına ilişkin faaliyet ve uygulamalara yer verilmemiştir. - "Düşük tüketim maliyetleri ile ilgili olarak" sadece atık sistemi ve su tasarrufuna ilişkin etkinliklere yer verilmiştir. $\mathrm{Bu}$ etkinliklerin çeşitlendirilmesi gerektiği düşünülmektedir.

- "Adil konut erişimi konusunda" ise, konut alanlarındaki park sayısının artırılmasına ve etkin/ ulaşılabilir bir atık sistemine ilişkin hedeflere yer verilmiş̧ir. 


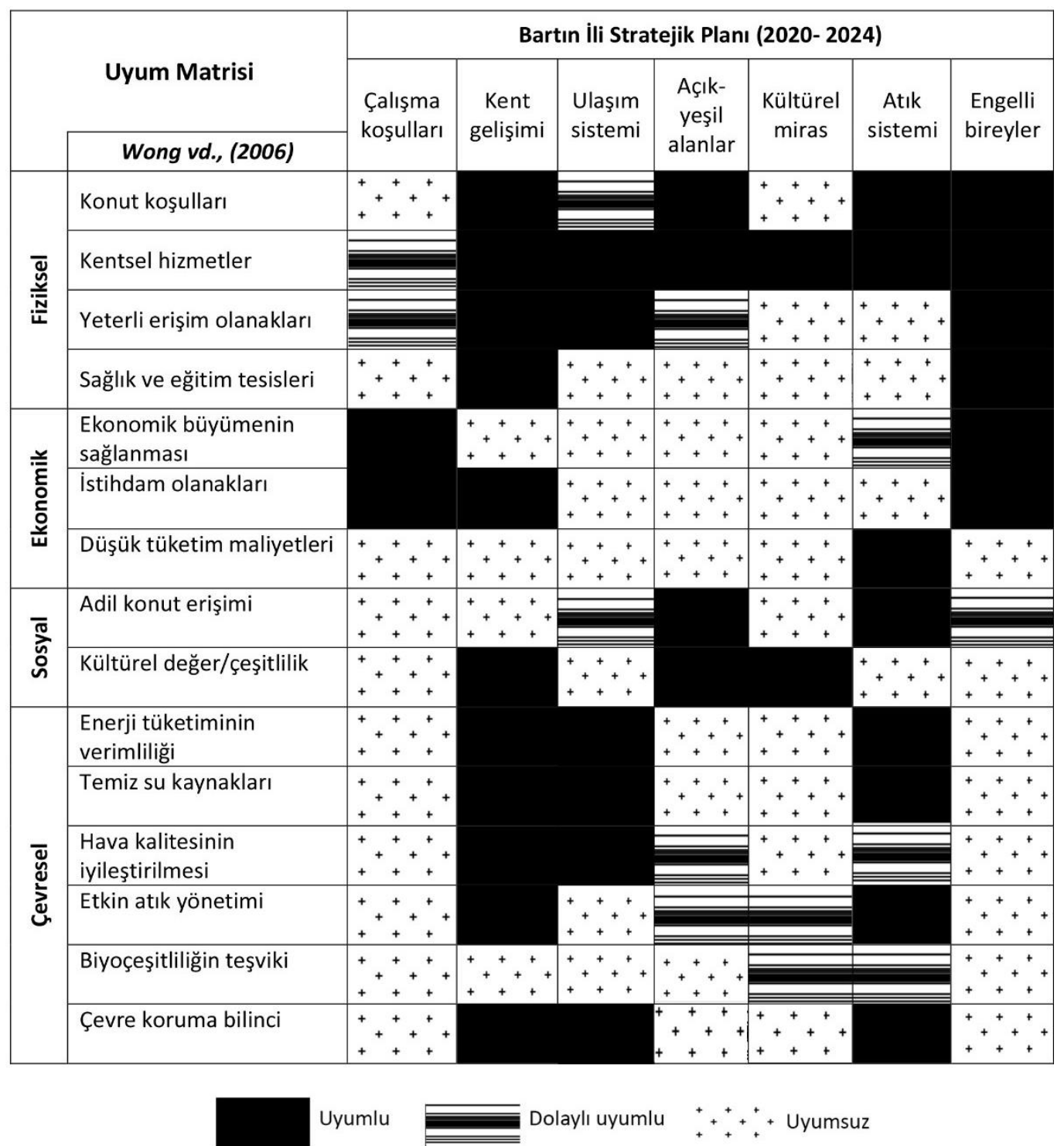

Şekil 1. Stratejik planın sürdürülebilirlik ölçütleri ile uyumu (Wong vd., 2006 ve Özel Mazlum \& Yalçıner Ercoşkun, 2019'dan yararlanılarak geliştirilmiştir)

Figure 1. Compliance of the strategic plan with the sustainability criteria

- "Kültürel değer ve çeşitlilik kapsamında", kentsel gelişim sürecinde kültürel değerlerin korunması ana yaklaşım olarak ele alınmış ve açıkyeşil alanların korunmasının önemine değinilmiştir.

- "Verimli enerji tüketimi konusunda" ise, atık dönüşüm uygulamalarından ve doğa dostu ulaşımın gerekliliğinden bahsedilmiştir. Kent genelinde her bireyin temiz su kaynaklarına erişim hakkı olduğuna değinilmiştir.

- "Hava kalitesinin iyileştirilmesi/ korunması" ana hedeflerden biri olarak ele alınmış ve bu bağlamda, doğa dostu ulaşımın desteklenmesi ve yaygınlaştırılmasına ilişkin stratejilere yer verilmiştir.

- "Biyoçeşitliliğin teşvikine ilişkin" olarak, tam uyum sağlayan bir madde olmadığı saptanmıştır. $\mathrm{Bu}$ bağlamda, kent gelişiminde "kültürel miras alanlarına ilişkin biyoçeşitliliğin korunması ve sürdürülebilirliğinin sağlanması"nın ana stratejilerden biri olarak ele alınması gerektiği düşünülmektedir. k1yaslamalarda; koruma yaklaşımı kentin kalkınmasında temel bir değer olarak ele alınmış ve kültürel yayınların basılmasından bahsedilmiştir ancak, koruma konusunda farkındalığın artırılmasına yönelik etkinliklere yer verilmemiştir.

\subsection{KENTGES ile uyumun belirlenmesine ilişkin matrisler}

3.3. Matrices for determining compliance with KENTGES

Stratejik planın (Bartın Belediyesi, 2019), KENTGES (2010-2023) (KENTGES, 2020) dokümanına uyumunun tespit edilebilmesi amaciyla gerçekleştirilen uyum matrisi Şekil 2'te yer almaktadır. 


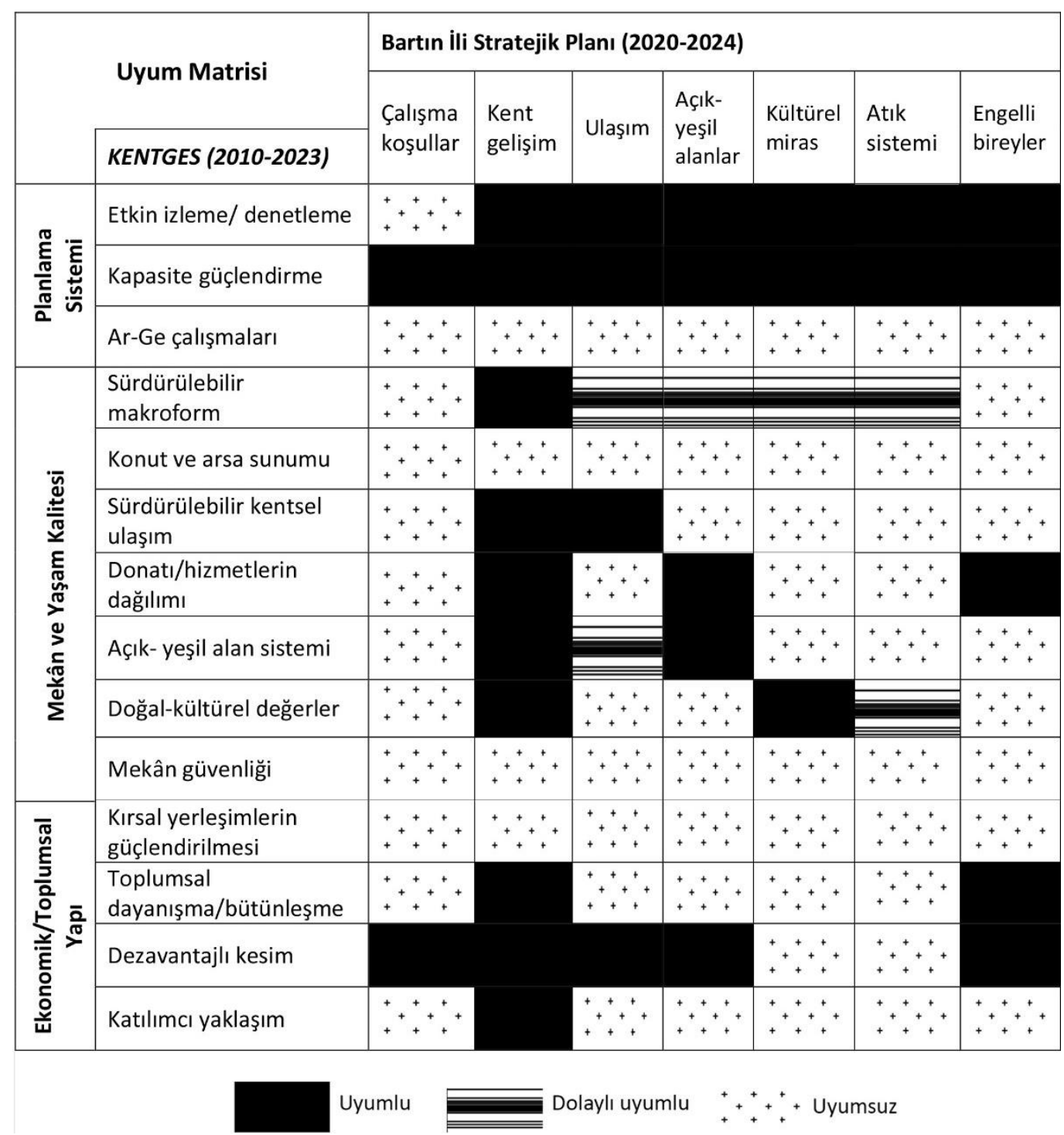

Şekil 2. Stratejik planın KENTGES ile Uyumu (Wong vd., 2006 ve Özel Mazlum \& Yalçıner Ercoşkun, 2019'dan yararlanılarak geliştirilmiştir).

Figure 2. Harmonization of the strategic plan with KENTGES

- "Çevre koruma bilincine ilișkin" gerçekleștirilen kıyaslamalarda; koruma yaklaşımı kentin kalkınmasında temel bir değer olarak ele alınmış ve kültürel yayınların basılmasından bahsedilmiştir ancak, koruma konusunda farkındalığın artırılmasına yönelik etkinliklere yer verilmemiştir.

- Stratejik planda, planlama sistemine ilişkin "etkin izleme ve denetlemenin" önemine değinilmiş ve "etkin kaynak kullanımı ve vatandaş memnuniyeti temelli" izleme/ denetlemelerin gerçekleştirilmesine ve bu bağlamda Strateji Geliştirme Kurulu tarafindan toplantılar gerçekleştirileceği ifade edilmiştir.

- "Kapasite güçlendirmeye ilişkin", kurumsal kapasitenin geliştirilmesi, kaynak verimliliği, paylaşım merkezlerinin ve gelir kaynaklarının geliştirilmesinden bahsedilmiştir. $\mathrm{Bu}$ bağlamda, söz konusu her madde ile ilişki saptanmıştır.

- “Ar-Ge çalışmalarına ilișkin”, idare bünyesinde bir ekibin bulunduğundan bahsedilmiş ancak, faaliyetler ve stratejilere yer verilmediği belirlenmiştir. Bu bağlamda söz konusu başlıklarla ilişkilendirme gerçekleştirilememiştir.

- "Sürdürülebilir makroform konusunda" ise; kentin sağlıklı, planlı ve kültürel değerlerin önemsendiği bir şekilde geliştirilmesinden bahsedilmiștir. Böylece, kent gelişimiyle sürdürülebilirlik ilişkisi kurulmuştur.

- Planda "konut ve arsa sunumuna ilișkin" bir stratejiye yer verilmediği belirlenmiştir. $\mathrm{Bu}$ kapsamda, konut ve arsa sunumuna yönelik sürdürülebilirlik ve yaşam kalitesini yükseltecek etkinlikler gerçekleştirilmesi gerektiği düşünülmektedir. 
- "Sürdürülebilir kentsel ulaşım başlığında" ise; sürdürülebilir kent gelişimi ve doğa dostu ulaşımın önemine değinilmiştir. Ancak; açık- yeşil alanlar ve kültürel miras alanları gibi kamusal alanlara entegre bir kentsel ulaşım sisteminden söz edilmediğinden bu maddelerle ilişki kurulamamıştır.

- "Donatıların/hizmetlerin dağılımına ilişkin", kent genelinde sosyal/ kültürel donatıların artırılmasına ve dengeli bir şekilde dağılımına değinilmiştir. Kültürel miras ve ulaşım gibi konulara yönelik bir ayrım olmadığından ilişkilendirme gerçekleştirilememiştir.

- Kent gelişiminde "doğal- kültürel değerlerin korunması" ana hedef olarak ele alınmıştır. Bu bağlamda, kültürel miras alanları ile uyumlu bir eşleşme saptanmıştır.

- Stratejik planda "mekân güvenliğinin artırılmasına ilişkin" faaliyetlere yer verilmediği görülmüştür. Kamusal mekândan kaynaklı güvenlik sorunları, kadınların kent hayatında aktif bir şekilde yer alabilmelerinde önemli bir engeldir (Açıksöz, 2017). Bu bağlamda cinsiyet eşitsizliğine maruz kalınan kentsel yerleşimlerde güvenlik, önemli bir konu olarak plan/ politika/ stratejilere yansitılmalıdır.

- Stratejik planın bir diğer eksik yönünün ise "kırsal yerleşimlerin güçlendirilmesine ilişkin" herhangi bir faaliyete yer verilmemesi olduğu düşünülmektedir. $\mathrm{Bu}$ bağlamda, belediye sınırı içinde yer alan kırsal peyzaj alanlarının sürdürülebilirliğine ilişkin stratejiler geliştirilmesi gerektiği düşünülmektedir.

- Engelli dostu belediyecilik anlayışının temel değer olarak ele alındığı planda "dezavantajlı kesimin yaşam kalitesinin iyileştirilmesine ilişkin"; kent gelişimi, ulaşım, parklar gibi kamusal konularda stratejiler geliştirilmiştir. Bu bağlamda, söz konusu başlıklara uyum saptanmıştır.

- "Katılımeı yaklaşıma ilişkin", katılımcılık kent gelişiminin temel değeri olarak ifade edilmiş ve ebelediye uygulamalarından söz edilmiştir.

\section{Tartışma ve sonuçlar}

\section{Discussion and conclusions}

Şehirler İttifakı (Cities Alliance)'na göre başarılı şehirlerde gerçekleştirilen uygulamalar; geçim kaynaklarının iyileştirilmesi, çevre kalitesi/ hizmet sunumu/ enerji verimliliğinin sağlanması, mekânsal form ve altyapı çözümlemeleri sunulması, mali kaynaklara yönelik düzenlemeler ve yönetişim anlayışının benimsenmesine ilişkin uygulamalar olarak belirtilmiştir (Cities Alliance, 2020). Bartın kentinin gelişiminin söz konusu KGS doğrultusunda yönlendirilmesi için uygulamalara aktif ve tam anlamıla yer verilmesinin önemi büyüktür.

Sürdürülebilir kent gelişiminin sağlanmasında kapsamlı çevre politikalarının rolü büyüktür. Mutlu (2006)'ya göre çevre politikalarında başarının sağlanmasında gerekli koşullar; yönetim maliyetlerinin düşürülmesi, ekonomik etkinlikler gerçekleştirilmesi, politikaların benimsenmesi, uygulamaların işlerliğine güvenilmesi, dinamik bir yapıda olması ve politik süreçlere uyumlu olması olarak belirtilmiştir (Toprak, 2006). Söz konusu başarı koşullarının Bartın kentine ilişkin stratejik dokümanlara uyarlanmasiyla beraber sürdürülebilirlik anlamında önemli adımlar atılacağı düşünülmektedir.

Stratejik planda "Adil/ Kullanışlı Mekânsal Biçim" başlığı altında yer alan, gerçekleşmesi hedeflenen eylemlerden biri "ailelere yönelik mekânların yaygınlaştırılması" olarak ifade edilmiştir. Çağdaş/ adil bir kent gelişiminde, sosyal dışlanmayı destekleyen her türlü uygulamadan uzak durulması ve kadın-erkek eşitliği konusu dikkate alınarak politikalar geliştirilmesi/ düzenlemeler yapılması gerektiği düşünülmektedir.

Bu çalışma kapsamında, Bartın iline ilişkin 20202024 y1lların kapsayan strateji belgesinin sürdürülebilir kentsel planlama/ yönetim ölçütlerine uyumluluğu ve KENTGES belgesine uyumluluğu sorgulanmıştır. Bu iki dokümanın kıyaslanmasıyla eksiklerden yola çıkılarak hazirlanan, planda yer verilen maddelere ek olarak Bartın kentinin "sürdürülebilir" gelişimde etkili olacağ 1 düşünülen önerilere yer verilmiştir. Söz konusu öneriler aşağıda yer almaktadır:

\section{Planlama sistemi}

- Kentsel saçaklanmanın en aza indirgenmesine yönelik planlama çalışmalarının gerçekleştirilmesi,

- Planlama faaliyetlerine "biyoçeşitliliğin korunması" düşüncesinin yön vermesi ve habitat alanlarının korunmasi/ izlenmesi,

- Kent planlamasında "tüketim maliyetlerinin düşürülmesi” düşüncesinin ana hedeflerden biri olması ve bu kapsamda, akıllı kentlerde uygulanan, sürdürülebilirliği destekleyen projelerden yararlanılması.

\section{Mekân ve yaşam kalitesi}

- Kentsel gelişimin doğru ve sürdürülebilir bir şekilde gerçekleştirilebilmesi için $\mathrm{Ar}-\mathrm{Ge}$ çalışmalarına gereken önemin gösterilmesi ve çalışmaların desteklenmesi, 
- Sürdürülebilir kentsel ulaşımın sağlanmasında, açık-yeşil alanlar ve tarihi alanlar ile bağlantı kurulmas1,

- Kültürel miras alanlarının kullanımlarının artırılmasında, ulaşım kolaylıklarının sağlanmas1,

- Kentsel yerleşimin mekân kalitesinin artırılması hususunda, konut koşullarının iyileştirilmesi,

- Sağlık ve eğitim tesislerinin sayı ve niteliklerinin yanında erişilebilirliklerinin de iyileştirilmesi.

\section{Ekonomik/toplumsal yapr}

- Engelli dostu belediye hizmetlerinin kapsami/ işlerliğine dair bilgi verilmesi ve engelli dostu çözümlemelerin artırılması,

- Engelli dostu belediye hizmetlerinde olduğu gibi aktif yaşlanmaya ilişkin ve kadın dostu kentsel hizmetler konusunda plan ve politikaların gerçekleştirilmesi,

- Kültürel miras alanlarının korunmasi ve ulusal/uluslararası turizm kapsaminda değerlendirilerek kentin tanıtılmasını ve kente ekonomik katkı sunmasını sağlayacak etkinliklerin gerçekleştirilmesi,

- Koruma bilincinin aşılanmasına ilişkin kültürel etkinlikler ve eğitimlerin gerçekleştirilmesi.

Gerçekleştirilen araştırma ile oluşturulan matrisler yardımıyla Bartın kentinin güncel strateji dokümanında kent gelişim stratejileri ve sürdürülebilirlik konusundaki eksiklikler belirlenmiştir. KGS'ye ilişkin plan ve politikaların oluşturulması, uygulanması ve izlenmesi sürecinde; bu eksikliklerin giderilmesinde yerel yönetimlerde istihdam edilen ilgili meslek disiplinlerinin yanı sıra Peyzaj Mimarı sayılarının da artırılması gerektiği düşünülmektedir. Ayrıca, doğal ve kültürel kaynakların sürdürülebilirliği, akıllı kent gelişim stratejileri ile ilişkili güncel yaklaşımlardan yararlanılmasının önemi vurgulanmaktadır. Gelecekte yapılacak çalışmalarda, akıllı/ sürdürülebilir kent gelişim stratejilerinin ve eylem planının oluşturulmasına yönelik araştırmalara yer verilmesinin bu konudaki literatüre katkı sunacağı düşünülmektedir.

\section{Teşekkür}

\section{Acknowledgement}

Makalenin incelenmesinde göstermiş oldukları sabır ve anlayıştan dolayı, ilgili editör ve hakemlere teşekkür edilmektedir.

\section{Yazar katkısı}

Author contribution

Araştırmacılardan Açıksöz; makalenin düzenlenmesi, ilerleyişinin denetlenmesi, ilgili tabloların/bulguların ve sonuç kısmının değerlendirilmesi hususunda (\%50 oranında) katk1 sunmuştur. Dinçtürk ise, makale fikrinin oluşturulması, literatür verilerin elde edilmesi, bulgular ve sonuç kısmının şekillendirilmesine yönelik (\%50 oranında) katkı sunmuştur.

\section{Etik beyanı}

Declaration of ethical code

$\mathrm{Bu}$ çalışmada, "Yükseköğretim Kurumları Bilimsel Araştırma ve Yayın Etiği Yönergesi”" kapsamında uyulması gerekli tüm kurallara uyulduğunu, bahsi geçen yönergenin "Bilimsel Araştırma ve Yayın Etiğine Aykırı Eylemler" başlığ1 altında belirtilen eylemlerden hiçbirinin gerçekleştirilmediğini taahhüt ederiz.

\section{Çıkar çatışmasıı beyanı \\ Conflicts of interest}

Yazarlar herhangi bir çıkar çatışması olmadığını beyan eder.

\section{Kaynaklar \\ References}

Açıksöz, S. (2017). Toplumsal cinsiyet eşit(siz)liğinin dış mekâna yansımaları: Toplumsal cinsiyete duyarlı bütçeleme. Çelikyay, S. (Ed), Toplumsal Cinsiyet ve Kent mekân Sempozyumu Bildiriler Kitabl (s. 114-138.). Ankara.

Akbulut, F. (2016). Kentsel ulaşım hizmetlerinin planlanması ve yönetiminde sürdürülebilir politika önerileri. Kastamonu Üniversitesi İktisadi ve İdari Bilimler Fakültesi Dergisi, 11(1), 336-355.

Bartın Belediyesi (2020). Stratejik plan (2020- 2024). https://bartin.bel.tr/dosyalar/2019/10/B.Belediye

Baş, H. (2018). Sürdürülebilir kent formu: yayılmaya karşı kompaktlaşma. Türkiye Kentsel Morfoloji Araştırma A $\breve{g}_{l}$ II. Kentsel Morfoloji Sempozyumu: "Değişkent" Değişen Kent, (ss. 105-115). İstanbul.

Can, A. (2014). Yerel yönetimler ve kültür politikaları bağlamında İstanbul'da kentsel koruma sorunsalına sürdürülebilir çözüm önerileri. Marmara Sosyal Araştırmalar Dergisi, 5, 55-81. 
Cites Alliance (2020, $12 \quad$ Aralık). https://www.citiesalliance.org/resources/knowle dge/cities-alliance-knowledge/guide-citydevelopment-strategies-improving-urban.

Çakmak, T., \& Yılmaz, B. (2017). Bellek kurumlarında dijitalleştirme ve dijital koruma: Türkiye'deki uygulamaların analizi. Bilgi Dünyası, 18(1), 4991. https://doi.org/10.15612/BD.2017.580

Demirayak, F. (2002). Biyolojik çeşitlilik-doğa koruma ve sürdürülebilir kalkınma. TÜBITAK VIZYON 2023 Projesi Çevre ve Sürdürülebilir Kalkınma Paneli (ss. 1-30). Ankara.

Demirkan, H. (2015). Mekânlarda erişilebilirlik, kullanılabilirlik ve yaşanabilirlik. Dosya 36(3), $1-5$.

Gül, A., \& Küçük, V. (2001). Kentsel açık-yeşil alanlar ve Isparta kenti örneğinde irdelenmesi. Süleyman Demirel Üniversitesi Orman Fakültesi Dergisi, 2, 27-48.

Güler, M., \& Turan, A. (2013). Türkiye'de sürdürülebilir kentsel gelişme stratejileri: KENTGES eylem planı (2010-2023) örneği. International Conference on Eurasian Economies 2013 (pp 255-260).

Gür, M., \& Erbil, Y. (2018). Konut ve konut çevresine ilişkin kullanıcı memnuniyeti araştırması: Bursa/Yıldırım. International Journal of Social Humanities Sciences Research (JSHSR), 5(30), 4135-4148.

Güven, A. (2017). Kentsel sorunların çözümünde kent yönetimi ve paydaşlarının rolü. Uluslararası Sosyal Araştırmalar Dergisi, 10(52), 10481062.

Karakurt Tosun, E. (2013). Sürdürülebilir kentsel gelişim sürecinde kompakt kent modelinin analizi. Yönetim ve Ekonomi, 20(1), 31-46.

Karataş, A., \& Kılıç, S. (2017). Sürdürülebilir kentsel gelişme ve yeşil alanlar. Journal of Political Sciences, 26(2), 53-78. https://doi.org/10.26650/siyasal.2017.26.2.0003

KENTGES (2020). Bütünleşik kentsel gelişme stratejisi ve eylem planı (2010-2023). https://webdosya.csb.gov.tr/db/kentges/editordo sya/kentges_tr.pdf

Kömürcü, B., \& Avşar Negiz, N. (2016). Kentsel bir sorun alanı olarak sokakta çalışan- çalıştırılan çocuklar: (Isparta örneği). Süleyman Demirel Üniversitesi İktisadi ve İdari Bilimler Fakültesi Dergisi, 21(3), 971-994.

Nilsson, K., Hasta Nielsen, T., Aalbers, C., Bell, S., Boitier, B., Chery, JP., Fertner, C., Groschowski, M., Haase, D., Loibl, W., Pauleit, S., Pintar, M.,
Piorr, A., Ravetz, J., Ristimäki, M., Rounsevell, M., Tosics, I., Westerink, J., \& Zasada, I. (2014). Strategies for sustainable urban development and urban rural linkages. Avrupa Mekansal Gelişim Dergisi, 1-26.

Öksüz Kuşçuoğlu, G., \& Taş, M. (2017). Sürdürülebilir kültürel miras yönetimi. Yalvaç Akademi Dergisi, 2(1), 58-67.

Önder, S., \& Polat, A. T. (2012). Kentsel açık-yeşil alanların kent yaşamındaki yeri ve önemi. Kentsel Peyzaj Alanlarının Oluşumu ve Bakım Esaslart Semineri (ss. 73-96). Konya.

Ören, K., \& Yüksel, H. (2013). Türkiye'de konut sorunu ve temel dinamikleri. Süleyman Demirel Üniversitesi Sosyal Bilimler Enstitüsü Dergisi, 2(18),47-84.

Özbilen, N., \& Gülersoy, N. Z. (2016). Kentsel gelişim ve dönüşüm planlanması sürecinde gayrimenkul mülkiyet haklarının değerlendirilmesi: imar hakları transferi plan uygulama arac1. Planlama, 26(3), 172-180. https://doi.org/10.14744/planlama.2016.22932

Özel Mazlum, Z., \& Yalçıner Ercoşkun, Ö. (2019). Kentsel dönüşüm strateji belgelerinde sürdürülebilirlik değerlendirmesi: Kilis örneği. Dirençlilik Dergisi, 3(2), 183-200. https://doi.org/10.32569/resilience.598083

Rasoolimanesh, S. M., Badarulzaman, N., \& Jaafar, M. (2011). Achievement to sustainable urban development using City Development Strategies (CDS): A comparison between Cities Alliance and the World Bank definitions. Journal of Sustainable Development, 4(5), 151-166.

Rasoolimanesh, S. M., Badarulzaman, N., \& Jaafar, M. (2012). City Development Strategies (CDS) and sustainable urbanization in developing World. Procedia-Social and Behavioral Sciences, 36, 623-631.

https://doi.org/10.1016/j.sbspro.2012.03.068.

Sat, N. A., Güler Üçer, Z. A., Varol, C., \& Yenigül, S.B. (2017). Sürdürülebilir kentler için çok merkezli gelişme: Ankara metropoliten kenti için bir değerlendirme. Ankara Araştırmalarl Dergisi, $5(1)$, 98-107. https://doi.org/10.5505/jas.2017.05025

TEMA (2020, $26 \quad$ Aralık). https://www.tema.org.tr/basin-odasi/basinbultenleri/tema-vakfindan-yerel-yonetimlerecagri.

Toprak, D. (2006). Sürdürülebilir kalkınma çerçevesinde çevre politikaları ve mali araçlar. Süleyman Demirel Üniversitesi Sosyal Bilimler Enstitüsü Dergisi, 2(4), 146-169. 
Ulubaş, A., \& Kocabaş, A. (2016). Sürdürülebilir kentsel koruma yaklaşımı bağlamında Eyüp tarihi dokusunun irdelenmesi. IV. Çevre-Tasarım Kongresi (ss. 73-84). Kayseri.

UN HABİTAT (2005). Lake Victoria Region City Development Strategies (CDS): for Improved Urban Environment and Poverty Reduction. Second Generation CDS Cities Induction Workshop Report. https://mirror.unhabitat.org/downloads/docs/358 9_53577_kampala_wkshp_rpt.pdf

Vural, H., Meral, A., \& Doğan, S. (2019). Kentsel gelişim ve yeşil alan planlama sürecinin katılımcı
SWOT analizi yöntemi ile değerlendirilmesi: Bingöl kenti. İdealkent, 10(28), 1069-1096. https://doi.org/10.31198/idealkent.607383

Wong, S. W., Tang, B., \& Horen, B. V. (2006). Strategic urban management in China: A case study of Guangzhou development district. Habitat International, 30(3), 645-667. https://doi.org/10.1016/j.habitatint.2005.04.001

Yücesu, Ö., Korkut, A., \& Kiper, T. (2017). Kırklareli kent merkezinin açık ve yeşil alanlarının analizi ve bir sistem önerisi. ARTIUM, 5(2), 22-37. 